ARTICLE

Received 11 Dec 2014 | Accepted 24 Feb 2015 | Published 10 Apr 2015

\title{
Multinuclear metal-binding ability of a carotene
}

\author{
Shinnosuke Horiuchi ${ }^{1}$, Yuki Tachibana1,2, Mitsuki Yamashita1,3, Koji Yamamoto1,3, Kohei Masai ${ }^{1,3}$, Kohei Takase ${ }^{2}$, \\ Teruo Matsutani ${ }^{2}$, Shiori Kawamata1, Yuki Kurashige, ${ }^{4,5}$, Takeshi Yanai ${ }^{4,5}$ \& Tetsuro Murahashi,3,6
}

Carotenes are naturally abundant unsaturated hydrocarbon pigments, and their fascinating physical and chemical properties have been studied intensively not only for better understanding of the roles in biological processes but also for the use in artificial chemical systems. However, their metal-binding ability has been virtually unexplored. Here we report that $\beta$-carotene has the ability to assemble and align ten metal atoms to afford decanuclear homoand heterometal chain complexes. The metallo-carotenoid framework shows reversible metalation-demetalation reactivity with multiple metals, which allows us to control the size of metal chains as well as the heterobimetallic composition and arrangement of the carotene-supported metal chains.

\footnotetext{
${ }^{1}$ Research Center of Integrative Molecular Systems (CIMoS), Institute for Molecular Science, National Institutes of Natural Sciences, Myodaiji, Okazaki, Aichi 444-8787, Japan. ${ }^{2}$ Department of Applied Chemistry, Graduate School of Engineering, Osaka University, Suita, Osaka 565-0871, Japan. ${ }^{3}$ Department of Structural Molecular Science, The Graduate University for Advanced Studies, Myodaiji, Okazaki, Aichi 444-8787, Japan. ${ }^{4}$ Department of Theoretical and Computational Molecular Science, Institute for Molecular Science, National Institutes of Natural Sciences, Myodaiji, Okazaki, Aichi 444-8585, Japan.

${ }^{5}$ Department of Functional Molecular Science, The Graduate University for Advanced Studies, Myodaiji, Okazaki, Aichi 444-8585, Japan. ${ }^{6}$ PRESTO, Japan Science and Technology Agency (JST), Myodaiji, Okazaki, Aichi 444-8787, Japan. Correspondence and requests for materials should be addressed to T.M. (email: mura@ims.ac.jp).
} 
C arotenoids are naturally abundant pigments containing extended $\pi$-conjugated $\mathrm{C}=\mathrm{C}$ double-bond arrays. The fascinating physical and chemical properties of carotenoids, such as light-harvesting, photo-protective, antioxidative and conductive properties have been explored not only for better understanding of their roles in biological processes but also for the use in artificial chemical systems ${ }^{1-4}$. An attractive, although yet undeveloped function of carotenoids is their metal-binding ability. While several early reports showed that carotenoids bind mononuclear metal moieties through conventional 1,3-butadienetype tetrahapto- $\pi$-coordination ${ }^{5-9}$, the extended $\pi$-conjugated polyene moieties in their backbones may impart the ability to bind a large metal-metal (M-M)-bonded array through continuous multiple $\pi$-coordination bonds (Fig. 1). Such potential multidentate bridging $\pi$-coordination ability of carotenoids is highly attractive because of its usefulness in inorganic synthesis. Indeed, chemists have sought to use polynucleating multidentate ligands as the scaffolds or templates to control the metal assembly that provides methodology to synthesize molecularly well-defined metal clusters for catalysis and materials science ${ }^{10-14}$. However, the scaffold strategy has been applied mostly to the construction of metal clusters with small size owing to the difficulty to design practically useful large scaffold ligands that can assemble and then hold many metal atoms. In fact, only few synthetic scaffold ligands that can bind 10 or more metal atoms through multidentate bridging coordination have been developed. Recently, Peng and colleagues ${ }^{15}$ developed synthetic multidentate $\mathrm{N}$-donor ligands that lead to isolation of $\mathrm{Ni}_{11}$ chain complexes. Shionoya and co-workers developed artificial metallo-DNA motifs that brought a method to construct a heterometal array of 10 metal ions, although direct $\mathrm{M}-\mathrm{M}$ bonds are absent in the metal array ${ }^{16}$. While these previous studies used the $\sigma$-type scaffolds bearing multiple hetero-atom $\sigma$ binding sites, $\pi$-type extended $\pi$-conjugated unsaturated hydrocarbon scaffolds are also promising in light of their preferable rows of $\mathrm{C}=\mathrm{C} \pi$-binding sites at regular intervals comparable to $\mathrm{M}-\mathrm{M}$ bond lengths ${ }^{17-20}$. Furthermore, relatively weak $\mathrm{C}=\mathrm{C} \pi$-coordination bond may cause dynamic metal binding at each $\mathrm{C}=\mathrm{C}$ site, which would be a key for assembling many metal atoms in a convergent manner. Carotenes are the rational choice as the extended $\pi$-conjugated scaffold for many metal atoms, because carotenes are one of the most readily available extended unsaturated hydrocarbons containing more than ten $\pi$-conjugated $\mathrm{C}=\mathrm{C}$ double bonds.

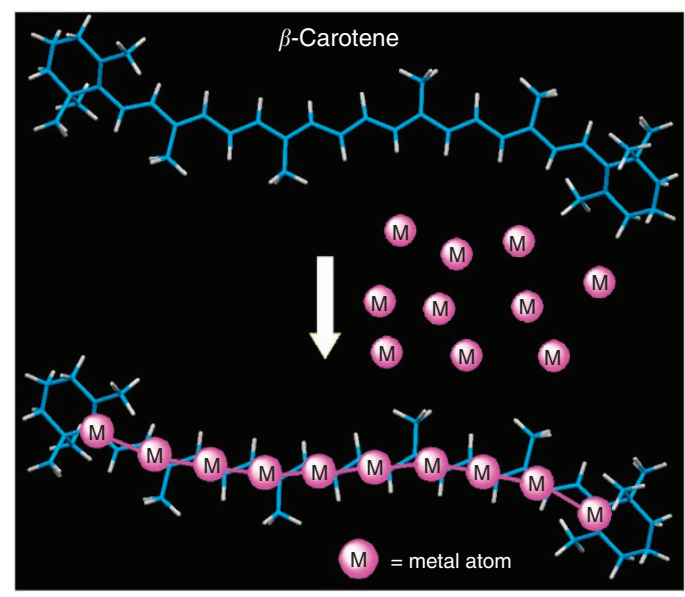

Figure 1 | Schematic representation of multinuclear metal binding by $\boldsymbol{\beta}$-carotene. Many metal atoms are assembled on the $\pi$-conjugated plane of $\beta$-carotene.
Herein, we report remarkable multinuclear metal-binding ability of $\beta$-carotene through synthesis and characterization of bis-( $\beta$-carotene $)$ decanuclear metal chain complexes. The metallo-carotene framework shows interesting multinuclear metalation-demetalation reactivity, allowing us to construct heterobimetallic decanuclear chain. The bis-( $\beta$-carotene) decanuclear metal chain complexes are stable rod-like sandwich molecules, exhibiting parallel $\pi-\pi$ stacking self-assembly in the crystalline state.

\section{Results}

Synthesis and structure of bis-( $\beta$-carotene) decanuclear Pd complexes. We examined the homoleptic carotene-metal systems in which all auxiliary ligands contained in the starting metal complexes are replaced by carotene to afford a sandwich-type multimetal-binding motif. Pd was used because of its feasibility to undergo convergent metal assembly with the aids of relatively weak metal-ligand and metal-metal bonds ${ }^{21,22}$. At first, we investigated the full metalation of the bis-carotene $\pi$-framework. The redox-condensation reaction of $\left[\mathrm{Pd}_{2}\left(\mathrm{CH}_{3} \mathrm{CN}\right)_{6}\right]\left[\mathrm{BF}_{4}\right]_{2}$ (ref. 23) and excess $\mathrm{Pd}_{2}(\mathrm{dba})_{3} \cdot \mathrm{C}_{6} \mathrm{H}_{6}$ (ref. 24) in the presence of $\beta$-carotene at $60^{\circ} \mathrm{C}$ gave the decanuclear palladium complex $\left[\mathrm{Pd}_{10}\left(\mu_{10}-\beta \text {-carotene }\right)_{2}\right]\left[\mathrm{B}\left(\mathrm{Ar}^{\mathrm{F}}\right)_{4}\right]_{2} \quad\left(1, \quad \mathrm{~B}\left(\mathrm{Ar}^{\mathrm{F}}\right)_{4}=\mathrm{B}\left(3,5-\left(\mathrm{CF}_{3}\right)_{2}\right.\right.$ $\left.\mathrm{C}_{6} \mathrm{H}_{3}\right)_{4}$ ) in $33 \%$ yield as a mixture of two isomers (Fig. 2a, 1meso:1-rac $=7: 3)$. It is noted that use of $\mathrm{Pd}_{2}(\mathrm{dba})_{3} \cdot \mathrm{CHCl}_{3}$ instead of $\mathrm{Pd}_{2}(\mathrm{dba})_{3} \cdot \mathrm{C}_{6} \mathrm{H}_{6}$ gave a complicated mixture from which 1 was not obtained. The major isomer (1-meso) is poorly soluble in $\mathrm{CH}_{3} \mathrm{CN}$, whereas another isomer (1-rac) is soluble, enabling us to separate the two isomers. The molecular structures of thus obtained yellow complexes 1-meso and 1-rac were determined by X-ray crystallographic analysis (Fig. 3). Remarkably, two $\beta$-carotene molecules flank an array of $10 \mathrm{Pd}$ atoms through unprecedentedly large $\mu_{10}$-bridging $\pi$-coordination. The two $\beta$-carotene ligands are stacking in an eclipsed form in 1-meso and in a staggered one in 1-rac. The nine Pd-Pd bond lengths $(2.5827(7)-2.7172(6) \AA$ in 1-meso; $2.6010(11)-2.7111(11) \AA$ in 1-rac) are shorter than that of bulk Pd $(2.76 \AA)$, indicating that $10 \mathrm{Pd}$ atoms in 1-meso or 1-rac are connected through Pd-Pd bonds (Supplementary Table 1). The calculated indices of Mayer bond order for each $\mathrm{Pd}-\mathrm{Pd}$ are ranged from 0.23 to 0.14 for 1-meso; cf., for a typical $\mathrm{Pd}-\mathrm{Pd}$-bonded complex, $\mathrm{Pd}_{2} \mathrm{Cl}_{2}\left(\mathrm{PH}_{3}\right)_{4}$, the index of Meyer bond order for Pd-Pd was calculated to be 0.60 . The $\beta$-carotene ligands in 1-meso showed reduced and inversed $\mathrm{C}=\mathrm{C} / \mathrm{C}-\mathrm{C}$ bond length alternation, that is, the long/short alternation $(1.46 / 1.41 \AA)$ was found for the inner nonaene substructure in the $\beta$-carotene ligands in 1-meso, being in between the $\mathrm{C}-\mathrm{C}$ bond lengths in ethane (1.54 $\AA$ ) and ethylene (1.34 $\AA$; cf. $1.33 / 1.47 \AA$ for the bond length alternation of free $\beta$-carotene; Fig. $3 e$ ). It is noted that the bis- $\beta$-carotene $\operatorname{Pd}_{10}$ chain dication of 1-meso formed infinite intermolecular $\pi-\pi$ stacking columns (the shortest intermolecular C . . C distance is $3.51 \AA$ ) in the crystalline state (Fig. 3f,g). Such intermolecular backbone $\pi-\pi$ stacking represents the typical property of the planar $\pi$-conjugated system. The dication of 1-rac formed the $\pi-\pi$ stacking dimer instead of the infinite column in the crystalline state. The ${ }^{1} \mathrm{H}$ and ${ }^{13} \mathrm{C}\left\{{ }^{1} \mathrm{H}\right\}$ nuclear magnetic resonance (NMR) spectra of 1-meso and 1-rac in $\mathrm{CD}_{2} \mathrm{Cl}_{2}$ showed that all olefinic proton and carbon resonances of the $\beta$-carotene ligands appeared at the high-field region (olefinic moieties appeared at $\delta=3.5-2.6 \mathrm{ppm}$ for ${ }^{1} \mathrm{H} ; \delta=111-69 \mathrm{ppm}$ for ${ }^{13} \mathrm{C}$ ), being consistent with the solid state structures determined by X-ray crystallography. The decanuclear sandwich complexes 1-meso and 1-rac are stable in solution even in the aerobic condition. Thus, it has been proven that bis- $\beta$-carotene 
a

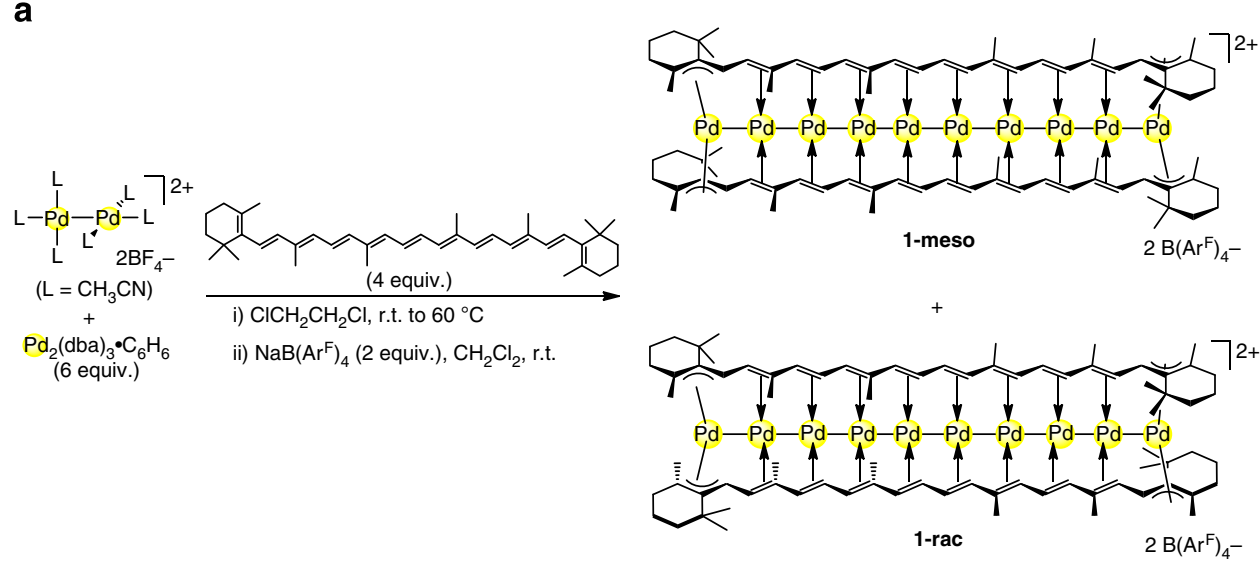

b

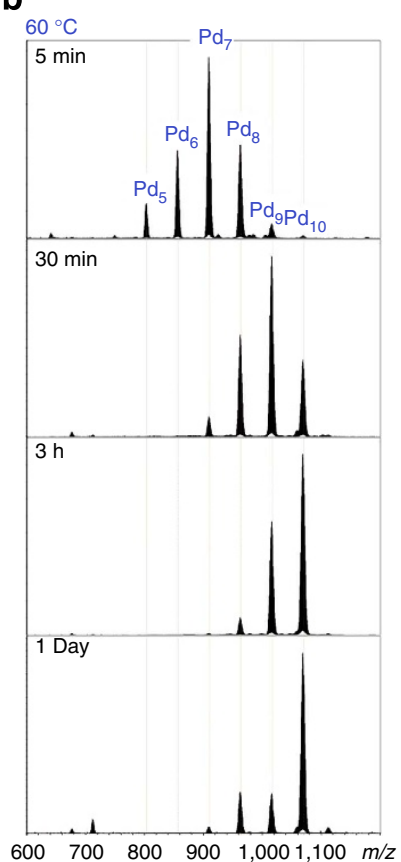

Figure 2 | Synthesis of bis-( $\beta$-carotene) $\mathbf{P d}_{\mathbf{1 0}}$ chain complexes. (a) Synthesis of $\left[\mathrm{Pd}_{10}\left(\mu_{10}-\beta \text {-carotene }\right)_{2}\right]\left[\mathrm{B}\left(\mathrm{Ar}^{\mathrm{F}}\right)_{4}\right]_{2}(\mathbf{1})$, (b) ESI-MS monitoring of the formation of $\mathbf{1}$ at $60^{\circ} \mathrm{C}$ showing the formation of metal-deficient intermediates $\left[\mathrm{Pd}_{n}(\beta \text {-carotene })_{2}\right]^{2+}(n=5,6,7,8$ and 9$)$.

$\pi$-framework can accommodate $10 \mathrm{Pd}$ atoms array through remarkable multidentate bridging $\pi$-coordination. The decanuclear complexes 1-meso and 1-rac are the soluble and isolable organometallic clusters having a long metal chain. Existence of long inorganic palladium wires in solution was recently reported, where di- or tetranuclear palladium units are self-assembled through Pd-Pd interactions ${ }^{25,26}$. The extended $(\pi-$ carbon framework)-(metal clusters) contact found in 1-meso and 1-rac may be related with the interface structure of the $\mathrm{sp}^{2}$ carbon material and metal clusters that is of current interests in materials science and catalysis ${ }^{27,28}$.

Synthesis and structure of bis-( $\beta$-carotene) decanuclear PdPt complexes. To further explore the metal-binding ability of $\beta$ carotene, we next examined the binding of bimetallic chains by bis- $\beta$-carotene $\pi$-framework. It was difficult to obtain a single bimetallic chain product simply by using $\mathrm{Pt}_{2}(\mathrm{dba})_{3}$ together with $\mathrm{Pd}_{2}(\mathrm{dba})_{3}$ in the synthetic reaction. We then thought a stepwise synthesis, that is, if metal-deficient bis- $\beta$-carotene complexes $\left[\mathrm{Pd}_{n}(\beta \text {-carotene })_{2}\right]^{2+}(n \leq 9)$ can be selectively constructed with
$\mathrm{Pd}$, subsequent incorporation of Pt may give bimetallic chains. The metal-deficient dications $\left[\operatorname{Pd}_{n}(\beta \text {-carotene })_{2}\right]^{2+}(5 \leq n \leq 9)$ were indeed observed when the formation of $\mathbf{1}$ (Fig. 2a) was monitored by electrospray ionization mass spectroscopy (ESI-MS; Fig. 2b). Upon mixing the starting materials at ambient temperature, $\mathrm{Pd}_{6}$ and $\mathrm{Pd}_{7}$ complexes of $\beta$-carotene were detected as the major MS-detectable species after $3 \mathrm{~h}$. Relatively small MS signals for $\mathrm{Pd}_{5}, \mathrm{Pd}_{8}$ and $\mathrm{Pd}_{9}$ complexes were also detected. Further incorporation of $\mathrm{Pd}$ into the bis- $\beta$-carotene framework proceeded gradually but was incomplete at ambient temperature after 2 days, resulting in that $\mathrm{Pd}_{7}$ and $\mathrm{Pd}_{8}$ complexes were the major MS-detectable species. Heating at $60^{\circ} \mathrm{C}$ resulted in shift of the distribution of products to higher nuclearity species, eventually affording the $\mathrm{Pd}_{10}$ chain complexes as the major MSdetectable product. However, it has been difficult to isolate and characterize each of metal-deficient products from the reaction mixtures of the build-up reaction. We confirmed the existence of regioisomers for a short chain model, that is, $\left[\mathrm{Pd}_{2}(1,10 \text {-diphenylpentaene })_{2}\right]\left[\mathrm{B}\left(\mathrm{Ar}^{\mathrm{F}}\right)_{4}\right]_{2}$, which was obtained by the reaction of $\left[\mathrm{Pd}_{2}(1,4 \text {-diphenyl-1,3-butadiene) })_{2}\right]\left[\mathrm{BF}_{4}\right]_{2}$ (ref. 29) with 1,10-diphenyl-1,3,5,7,9-decapentaene at room temperature 
a

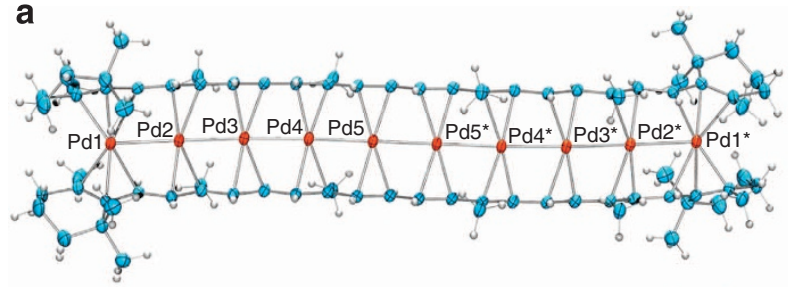

b

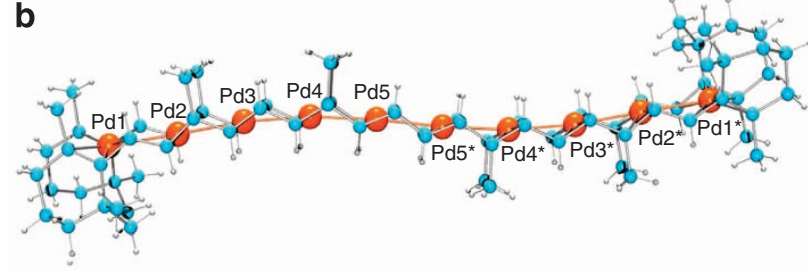

C

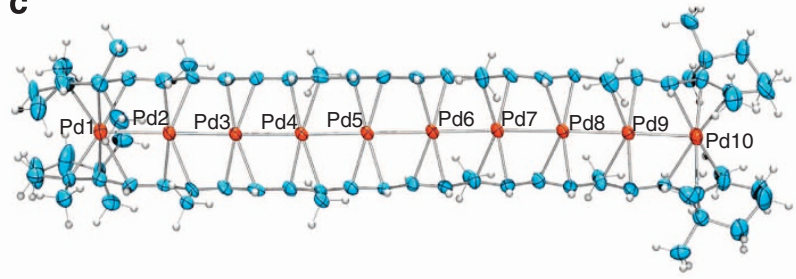

d

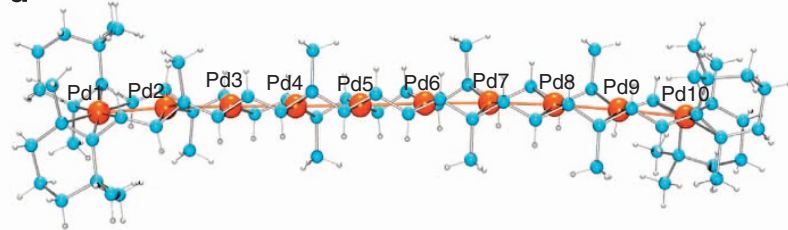

e

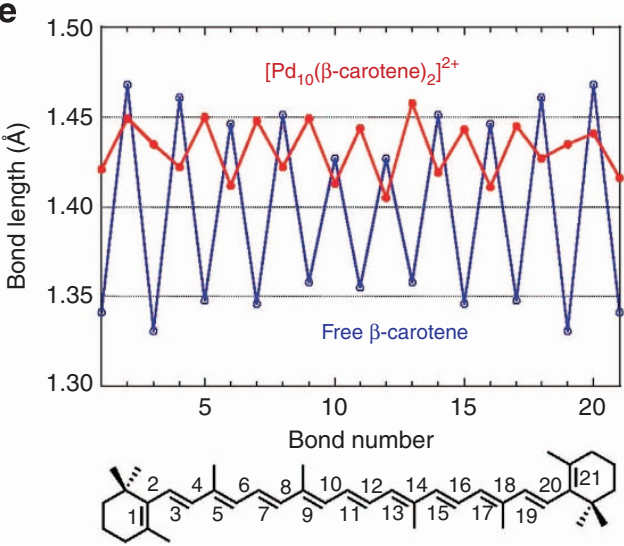

f

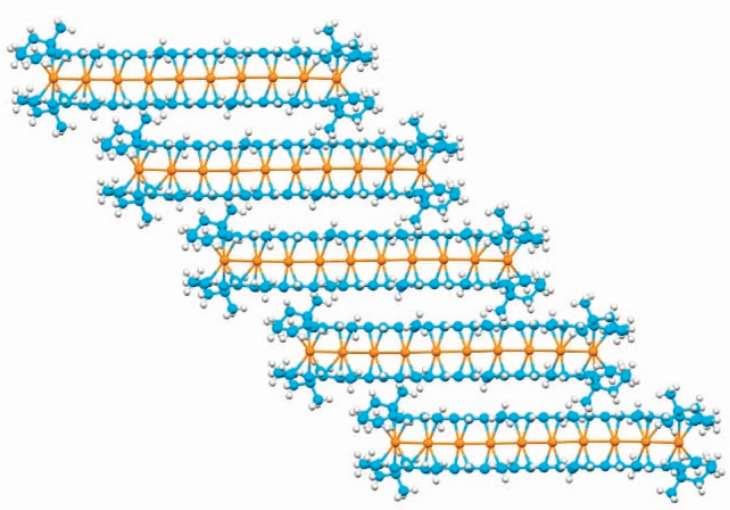

g

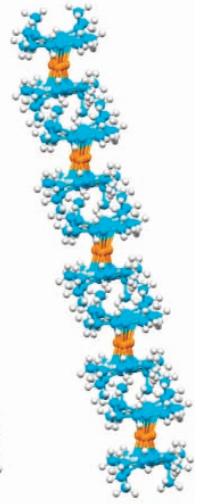

Figure 3 | Structures of bis-( $\beta$-carotene) $\mathbf{P d}_{\mathbf{1 0}}$ chain complexes. (a) Thermal ellipsoid (50\%) drawing of meso- $\left[\mathrm{Pd}_{10}\left(\mu_{10}-\beta-\operatorname{carotene}\right)_{2}\right]\left[B\left(\mathrm{Ar}^{\mathrm{F}}\right)_{4}\right]_{2}$ (1-meso). (b) Ball-stick drawing of 1-meso. (c) Thermal ellipsoid (30\%) drawing of rac- $\left[\mathrm{Pd}_{10}\left(\mu_{10}-\beta \text {-carotene }\right)_{2}\right]\left[B(\operatorname{Ar})_{4}\right]_{2}($ 1-rac). (d) Ball-stick drawing of 1-rac. (e) C-C bond lengths in 1-meso and free $\beta$-carotene (CCDC-253816), determined by X-ray structural analyses. (f) A view of a part of an intermolecular backbone $\pi-\pi$ stacking column of 1-meso in the crystalline state. (g) A side view of a part of the $\pi-\pi$ stacking column of 1-meso. For $\mathbf{a}-\mathbf{d}, \mathbf{f}, \mathbf{g}$, $\mathrm{B}\left(\mathrm{Ar}^{\mathrm{F}}\right)_{4}$ anions and non-coordinating solvent molecules were omitted for clarity.

(r.t.), contained four regioisomers $(57: 27: 10: 6)$ as shown in Supplementary Fig. 1.

We then found that the metal-deficient complexes of $\beta$-carotene can be obtained as a single product by demetalation from the $\mathrm{Pd}_{10}$ complex 1-meso with $\mathrm{CO}$. Thus, the reaction of 1 with $\mathrm{CO}(1$ atmosphere $(\mathrm{atm}))$ at $5{ }^{\circ} \mathrm{C}$ for 1 day afforded $\left[\mathrm{Pd}_{5}(\beta \text {-carotene })_{2}\right]\left[\mathrm{B}\left(\mathrm{Ar}^{\mathrm{F}}\right)_{4}\right]_{2}$ (2-meso) in $74 \%$ yield, together with a significant amount of Pd black (Fig. 4a). ${ }^{13} \mathrm{C}\left\{{ }^{1} \mathrm{H}\right\}$ NMR analysis as well as the single-crystal $\mathrm{X}$-ray structure analysis of 2-meso showed that the $\mathrm{Pd}_{5}$ chain occupied the half-part of the bis- $\beta$-carotene framework (Fig. 5a). The ESI-MS monitoring experiments on the demetalation reaction with $\mathrm{CO}(1 \mathrm{~atm})$ at $0^{\circ} \mathrm{C}$ showed that the starting $\mathrm{Pd}_{10}$ complex 1-meso and the half-filled $\mathrm{Pd}_{5}$ complex 2-meso were present as the major MS-detectable species during the reaction (Fig. $4 \mathrm{~b}$ ). The prolonged reactions for 1 week resulted in gradual increase of the MS signal for the $\mathrm{Pd}_{4}$ complex. The $\mathrm{Pd}_{7}$ complex $\left[\mathrm{Pd}_{7}(\beta \text {-carotene })_{2}\right]\left[\mathrm{B}\left(\mathrm{Ar}^{\mathrm{F}}\right)_{4}\right]_{2}$ (3meso) was also obtained by exposing 1-meso to $\mathrm{CO}(1 \mathrm{~atm})$ at $30^{\circ} \mathrm{C}$ for $3 \mathrm{~h}$ in $20 \%$ yield (Fig. $4 \mathrm{a}$ ). During this reaction, the major ESI-MS-detectable species were the starting $\mathrm{Pd}_{10}$ complex and the $\mathrm{Pd}_{7}$ complex (Supplementary Fig. 2), while the prolonged reactions resulted in further demetalation. The ${ }^{13} \mathrm{C}\left\{{ }^{1} \mathrm{H}\right\}$ NMR analysis as well as the single-crystal $\mathrm{X}$-ray structure analysis (Fig. 5b) showed that the $\mathrm{Pd}_{7}$ chain was located in the bis- $\beta$ carotene framework. The demetalation of 3-meso with $\mathrm{CO}$ ( $1 \mathrm{~atm})$ at $0^{\circ} \mathrm{C}$ occurred rapidly to afford 2-meso with complete consumption of 3-meso within $15 \mathrm{~min}$. Thus, the pseudo- superposed $\beta$-carotene stacking structure was preserved during the demetalation under a $\mathrm{CO}$ atmosphere, giving a single regioisomer of metal-deficient sandwich. The results of the ESIMS monitoring experiments suggested that the loss of a $\mathrm{Pd}^{0}$ atom from the $\mathrm{Pd}_{10}$ complex and from the $\mathrm{Pd}_{5}$ or $\mathrm{Pd}_{7}$ complex are relatively slow. The loss of $\mathrm{Pd}^{0}$ likely occurs from one end of the $\mathrm{Pd}$ chain, while it is not easy to explain the reason why the demetalation almost stopped at the $\mathrm{Pd}_{5}$ species or the $\mathrm{Pd}_{7}$ species in each reaction condition. There may be several factors that affect aggregation and dissociation of metals and organic ligands (for example, M-CO affinity ${ }^{30}$, M-carotene bond dissociation and $\mathrm{M}-\mathrm{M}$ bond dissociation). In the case of associative ligand exchange, the relatively slow release of $\mathrm{Pd}^{0}$ from the filled $\mathrm{Pd}_{10}$ complex is probably due to the lower accessibility of the terminal $\mathrm{Pd}$ atoms, which are sterically hindered by the bulky terminal $\beta$-groups of the $\beta$-carotene ligands, to $\mathrm{CO}$. Consistently, demetalation from the $\mathrm{Pd}_{7}$ complex, where one end of the $\mathrm{Pd}_{7}$ chain is less hindered by ligands, occurred much faster at $0^{\circ} \mathrm{C}$ than that from the $\mathrm{Pd}_{10}$ complex.

We next confirmed that metal-refilling reaction from isolated metal-deficient complexes proceeds smoothly by using the $\mathrm{Pd}_{5}$ complex 2-meso, that is, addition of $\mathrm{Pd}_{2}(\mathrm{dba})_{3} \cdot \mathrm{C}_{6} \mathrm{H}_{6}$ to 2-meso in $\mathrm{C}_{2} \mathrm{D}_{4} \mathrm{Cl}_{2}$ at $60^{\circ} \mathrm{C}$ afforded the $\mathrm{Pd}_{10}$ complex 1 -meso $(41 \%$ yield). We then tested whether metal refilling of 2-meso with $\mathrm{Pt}^{0}$ is possible. Thus, the bimetallic $\mathrm{Pd}_{5} \mathrm{Pt}_{3}$ chain complex $\left[\mathrm{Pd}_{5} \mathrm{Pt}_{3}(\beta\right.$ carotene $\left.)_{2}\right]\left[\mathrm{B}\left(\mathrm{Ar}^{\mathrm{F}}\right)_{4}\right]_{2}$ (4-meso) was formed by treatment of 2 meso with $\mathrm{Pt}_{2}(\mathrm{dba})_{3} \cdot \mathrm{CHCl}_{3}$ in the presence of ethylene (1 atm) 
a

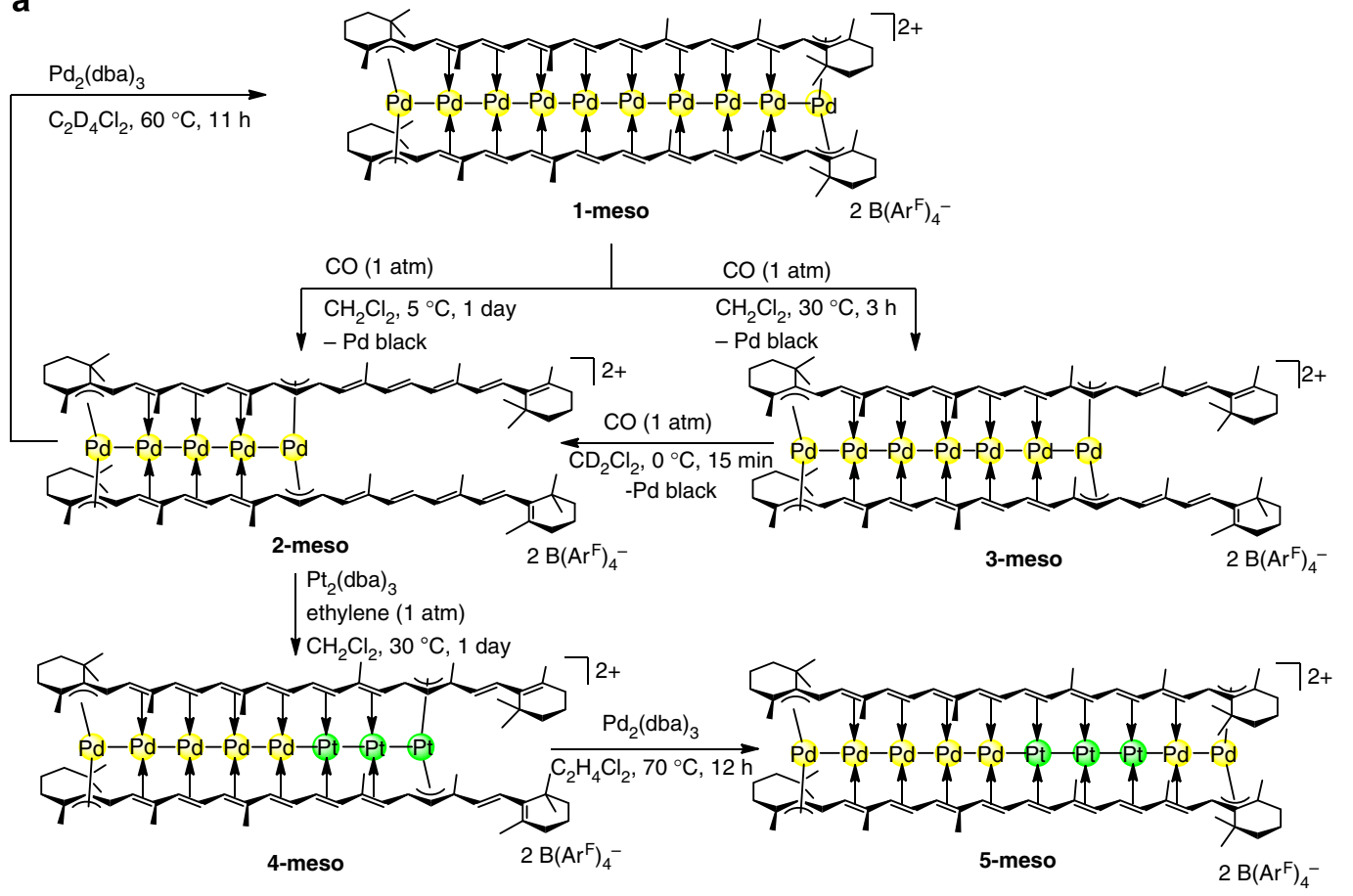

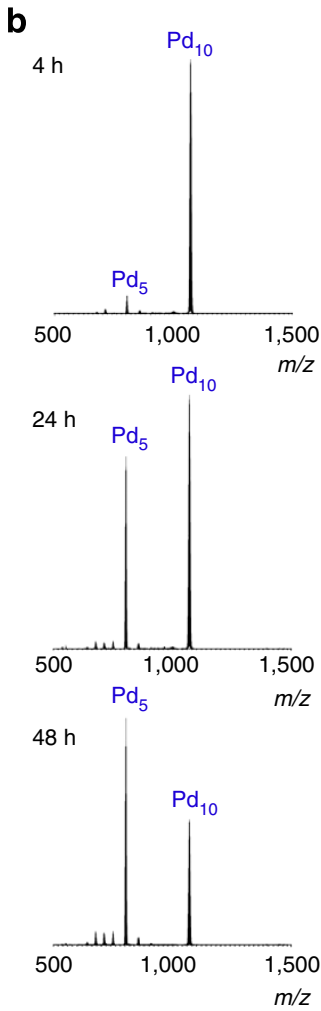

Figure 4 | Synthesis of bimetallic PdPt chain sandwich complexes of $\boldsymbol{\beta}$-carotene. (a) Demetalation and metalation of bis- $\beta$-carotene framework. Demetalation of 1-meso with $\mathrm{CO}$ afforded the metal-deficient complex $\left[\mathrm{Pd}_{5}\left(\mu_{5}-\beta \text {-carotene }\right)_{2}\right]\left[\mathrm{B}\left(\mathrm{Ar}^{\mathrm{F}}\right)_{4}\right]_{2}(\mathbf{2}-\mathbf{m e s o})$ or $\left[\mathrm{Pd} 7\left(\mu_{7}-\beta-\operatorname{carotene}\right)_{2}\right]\left[\mathrm{B}\left(\mathrm{Ar}^{\mathrm{F}}\right)_{4}\right]_{2}$ (3-meso). Subsequent metalation of 2-meso with $\mathrm{Pt}^{0}$ and then with $\mathrm{Pd}^{0}$ gave a mixed metal complex $\left[\mathrm{Pd}_{5} \mathrm{Pt}_{3}\left(\mu_{8}-\beta-\operatorname{carotene}\right)_{2}\right]\left[\mathrm{B}\left(\mathrm{Ar}^{\mathrm{F}}\right)_{4}\right]_{2}(\mathbf{4}-\mathbf{m e s o})$ and $\left[\mathrm{Pd}_{5} \mathrm{Pt}_{3} \mathrm{Pd}_{2}\left(\mu_{10}-\beta \text {-carotene }\right)_{2}\right]\left[\mathrm{B}\left(\mathrm{Ar}^{\mathrm{F}}\right)_{4}\right]_{2}$ (5-meso), respectively. (b) ESI-MS monitoring of the demetalation from 1-meso at $0^{\circ} \mathrm{C}$ under $\mathrm{CO}(1$ atm) atmosphere.

a

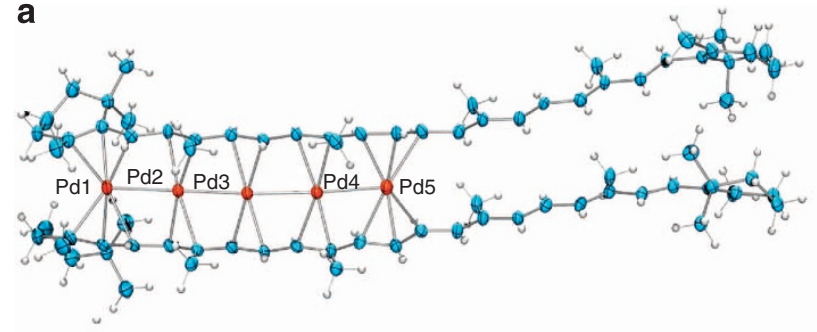

b

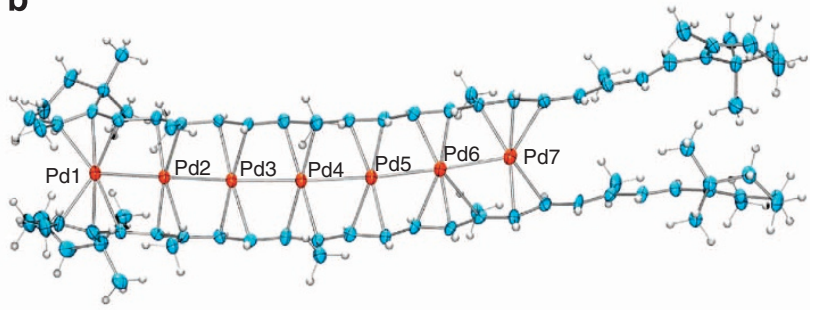

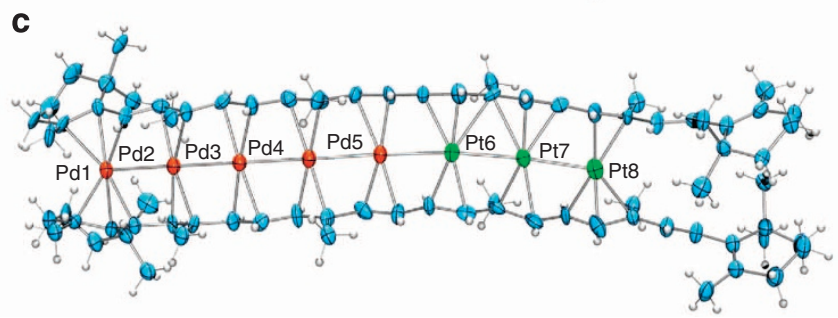

Figure 5 | Structures of metal-deficient sandwich complexes of $\boldsymbol{\beta}$-carotene. (a) Thermal ellipsoid (30\%) drawing of $\left[\mathrm{Pd}_{5}\left(\mu_{5}-\beta-\operatorname{carotene}\right)_{2}\right]\left[\mathrm{B}\left(\mathrm{Ar}^{\mathrm{F}}\right)_{4}\right]_{2}$ (2-meso). (b) Thermal ellipsoid (30\%) drawing of $\left[\mathrm{Pd}_{7}\left(\mu_{7}-\beta \text {-carotene }\right)_{2}\right]\left[\mathrm{B}\left(\mathrm{Ar}^{\mathrm{F}}\right)_{4}\right]_{2}$ (3-meso). (c) Thermal ellipsoid $(30 \%) \mathrm{drawing}$ of $\left[\mathrm{Pd}_{5} \mathrm{Pt}_{3}\left(\mu_{8}-\beta\right.\right.$ carotene) $\left.)_{2}\right]\left[\mathrm{B}\left(\mathrm{Ar}^{\mathrm{F}}\right)_{4}\right]_{2}$ (4-meso). For $\mathbf{a}-\mathbf{c}, \mathrm{B}\left(\mathrm{Ar}^{\mathrm{F}}\right)_{4}$ anions and non-coordinating solvent molecules were omitted for clarity. The coordination modes of two $\beta$-carotene ligands in the crystalline 3-meso or 4-meso are slightly different. Furthermore, in the crystal structures of the metal-deficient complexes, 2-meso, 3-meso and 4-meso, the uncoordinated cyclohexenyl group are not superposed due to the rotation at C6-C7 bond. The NMR spectra of 2-meso, 3-meso or 4-meso showed only a single set of $\beta$-carotene signals.

at $30{ }^{\circ} \mathrm{C}$ for 1 day (59\% yield; Fig. 4a). In the absence of ethylene, the metalation with $\mathrm{Pt}_{2}(\mathrm{dba})_{3}$ did not proceed at the present condition. Addition of ethylene generated Pt-ethylene complexes in situ, which might be more reactive and soluble than $\mathrm{Pt}_{2}(\mathrm{dba})_{3}$ (ref. 31). The $\mathrm{Pd}_{5}-\mathrm{Pt}_{3}$ mixed metal arrangement in 4-meso was confirmed by X-ray crystallographic analysis (Fig. $5 \mathrm{c}$ ). The $\mathrm{Pd}_{5}$ chain $(\mathrm{Pd}-\mathrm{Pd}=2.731(2)-2.629(2) \AA)$ and the $\mathrm{Pt}_{3}$ chain $(\mathrm{Pt}-$ $\mathrm{Pt}=2.6612(9)$ and 2.6864(10) $\AA$ ) are connected through Pd-Pt 
bond $(2.657(2) \AA)$. The $\mathrm{Pd}_{5} \mathrm{Pt}_{3}$ arrangement was also confirmed by ${ }^{13} \mathrm{C}$ NMR analyses in $\mathrm{CD}_{2} \mathrm{Cl}_{2}$ where only one set of $\beta$-carotene signals was observed at $25^{\circ} \mathrm{C}$, and ${ }^{13} \mathrm{C}$ signals for Pt-bound carbons appeared at relatively higher field compared with those for Pd-bound carbons. Further metalation of 4-meso with $\mathrm{Pd}_{2}(\mathrm{dba})_{3} \cdot \mathrm{C}_{6} \mathrm{H}_{6}$ at $70^{\circ} \mathrm{C}$ gave decanuclear bimetallic chain complex $\left[\mathrm{Pd}_{5} \mathrm{Pt}_{3} \mathrm{Pd}_{2}(\beta \text {-carotene })_{2}\right]\left[\mathrm{B}\left(\mathrm{Ar}^{\mathrm{F}}\right)_{4}\right]_{2}$ (5-meso) (Fig. $\left.4 \mathrm{a}\right)$. The alternative metal arrangement, $\mathrm{Pd}_{5}-\mathrm{Pt}_{3}-\mathrm{Pd}_{2}$ was confirmed by assignment of the upfield shifted Pt-bound carbons of the $\beta$-carotene ligands in ${ }^{13} \mathrm{C}\left\{{ }^{1} \mathrm{H}\right\} \mathrm{NMR}$ analyses in $\mathrm{CD}_{2} \mathrm{Cl}_{2}$, that is, the substantial upfield shifts of the Pt-bound carbons of the $\beta$-carotene ligands in 5-meso relative to those in 1-meso $(\Delta \delta=8-13 \mathrm{ppm})$ were observed, while the chemical shifts of the Pd-bound carbons in 5-meso are similar to those in 1-meso $(\Delta \delta=0-2 \mathrm{ppm})$. Thus, $\beta$-carotene has the ability to bind bimetallic decanuclear chain, where stepwise demetalationmetalation sequence is useful in controlling the bimetal arrangement. Such reversible accommodation/liberation of multinuclear metal atoms has rarely been attained in metal cluster chemistry ${ }^{32}$, representing a facile dynamic metal-binding feature derived from weakly coordinating olefin $\pi$-coordination ${ }^{33,34}$ as well as $\mathrm{M}-\mathrm{M}$ bonds in organometallic sandwich frameworks ${ }^{35}$.

\begin{abstract}
Absorption spectra of bis-( $\beta$-carotene) Pd complexes. It is noted that $\left[\mathrm{Pd}_{n}(\beta \text {-carotene })_{2}\right]\left[\mathrm{B}\left(\mathrm{Ar}^{\mathrm{F}}\right)_{4}\right]_{2}$ showed a nuclearity-dependent absorption profile, that is, the red-shift of maximum absorption bands was observed according to decrease of the number of $\mathrm{Pd}$ atoms $(362 \mathrm{~nm}$ for 1-meso, $373 \mathrm{~nm}$ for 3-meso and $468 \mathrm{~nm}$ for 2meso) (Supplementary Fig. 3). The absorption spectra were well described by the time-dependent density functional theory calculations at the Coulomb-attenuated B3LYP level ${ }^{36}$, suggesting that (i) the absorption bands originate mainly from the ligand-to-metal charge transfer (Supplementary Fig. 4 and Supplementary Table 2) and (ii) the observed red-shift with decreasing number of Pd atoms reflects the increasing stabilization of lower-lying unoccupied molecular orbitals that have antibonding character for $d \sigma(\mathrm{M})$ $d \sigma(\mathrm{M})$ and $d(\mathrm{M})-p(\mathrm{~L})$ orbital interactions (Supplementary Figs 5-7 and Supplementary Tables 3-5). Visible-light irradiation resulted in the formation of $\mathbf{1}$ without heating, that is, the reaction similar to Fig. 2a with visible light irradiation (Xenon lamp, $>385 \mathrm{~nm}$ ) yielded $\mathbf{1}$ at $20^{\circ} \mathrm{C}$ in $24 \%$ yield (1-meso:1-rac $\left.=7: 3\right)$ (Supplementary Fig. 8 and Supplementary Methods).
\end{abstract}

\section{Discussion}

In this report, it has been proven that $\beta$-carotene, a naturally abundant and readily available unsaturated hydrocarbon pigment, has the ability to bind decanuclear homo- and heterometal chains through unprecedentedly large $\mu_{10}$-bridging $\pi$-coordination. The present results showed that natural extended $\pi$ conjugated unsaturated hydrocarbons can be utilized as the multidentate $\pi$-scaffolds for the construction of giant metal clusters. Future studies will focus on the physical and chemical properties of the rod-like bis-carotene decametal chain sandwich complexes, such as self-assembling behaviour, multielectron redox behaviour and charge mobility.

\footnotetext{
Methods

Synthesis and characterization of compounds. All manipulations were conducted under a nitrogen atmosphere using standard Schlenk or drybox techniques. The $\beta$-carotene-metal complexes were characterized by elemental analyses, ESIMS analyses and NMR. The assignment of each resonance in NMR analysis was made with aid of heteronuclear single-quantum correlation (HSQC) or heteronuclear multiple-quantum correlation (HMQC) and heteronuclear multiplebond correlation (HMBC) techniques. Furthermore, the five complexes (1-meso, 1rac, 2-meso, 3-meso and 4-meso) were structurally determined by X-ray crystallographic analyses (Supplementary Data 1-5).
}

Synthesis of $\left[\mathrm{Pd}_{10}(\beta \text {-carotene })_{2}\right]\left[\mathrm{B}\left(\mathbf{A r}^{\mathbf{F}}\right)_{4}\right]_{2}$ (1-meso) and (1-rac). To a suspension of $\beta$-carotene $(679 \mathrm{mg}, 1.27 \mathrm{mmol})$ in $\mathrm{ClCH}_{2} \mathrm{CH}_{2} \mathrm{Cl}(200 \mathrm{ml})$ were added $\mathrm{Pd}_{2}(\mathrm{dba})_{3} \cdot\left(\mathrm{C}_{6} \mathrm{H}_{6}\right)(1.89 \mathrm{~g}, 1.90 \mathrm{mmol})$ and $\left[\mathrm{Pd}_{2}\left(\mathrm{CH}_{3} \mathrm{CN}\right)_{6}\right]\left[\mathrm{BF}_{4}\right]_{2}(200 \mathrm{mg}$, $0.316 \mathrm{mmol})$ at r.t. The reaction mixture was stirred under nitrogen atmosphere at $60^{\circ} \mathrm{C}$ for 1 day. The reaction mixture was filtered and the filtrate was dried in vacuo The obtained brown powder and $\mathrm{NaB}\left(\mathrm{Ar}^{\mathrm{F}}\right)_{4}(560 \mathrm{mg}, 0.632 \mathrm{mmol})$ was added to $\mathrm{CH}_{2} \mathrm{Cl}_{2}$, and the mixture was stirred for 5 min at r.t. $\mathrm{Et}_{2} \mathrm{O}$ was added to the solution and the mixture was filtered. The filtrate was dried in vacuo to yield a red powder. After washing with $\mathrm{CH}_{3} \mathrm{CN}$, $\left[\mathrm{Pd}_{10}(\beta \text {-carotene })_{2}\right]\left[\mathrm{B}\left(\mathrm{Ar}^{\mathrm{F}}\right)_{4}\right]_{2}$ (1-meso) was isolated as an yellow powder $(290 \mathrm{mg}, 24 \%)$. $\left[\mathrm{Pd}_{10}(\beta \text {-carotene })_{2}\right]\left[\mathrm{B}\left(\mathrm{Ar}^{\mathrm{F}}\right)_{4}\right]_{2}(\mathbf{1}$-rac $)$ was obtained by recrystallization from the $\mathrm{CH}_{3} \mathrm{CN}$ solution $(107 \mathrm{mg}, 9 \%)$. For 1-meso: ${ }^{1} \mathrm{H}$ NMR (400 MHz, $\left.\mathrm{CD}_{2} \mathrm{Cl}_{2}, 25^{\circ} \mathrm{C}\right): \delta-0.27(\mathrm{~s}, 12 \mathrm{H}),-0.15(\mathrm{~s}, 12 \mathrm{H}), 0.33(\mathrm{~s}, 12 \mathrm{H}), 1.54(\mathrm{~s}$, 12H), $1.64(\mathrm{~m}, 4 \mathrm{H}), 1.78(\mathrm{~m}, 4 \mathrm{H}), 1.99(\mathrm{~m}, 4 \mathrm{H}), 2.08(\mathrm{~m}, 4 \mathrm{H}), 2.10(\mathrm{~s}, 12 \mathrm{H}), 2.65(\mathrm{~d}$, $J=12 \mathrm{~Hz}, 4 \mathrm{H}), 2.66(\mathrm{~d}, J=12 \mathrm{~Hz}, 4 \mathrm{H}), 2.86(\mathrm{dd}, J=3 \mathrm{~Hz}, J=9 \mathrm{~Hz}, 4 \mathrm{H}), 2.95(\mathrm{~d}$, $J=12 \mathrm{~Hz}, 4 \mathrm{H}), 3.04-3.11(\mathrm{~m}, 8 \mathrm{H}), 3.28-3.45(\mathrm{~m}, 8 \mathrm{H}), 3.47(\mathrm{t}, J=12 \mathrm{~Hz}, 4 \mathrm{H}), 7.50(\mathrm{~s}$, $\left.8 \mathrm{H}, p-B\left(A r^{F}\right)_{4}\right), 7.65\left(\mathrm{~s}, 16 \mathrm{H}, o-B\left(A r^{F}\right)_{4}\right) .{ }^{13} \mathrm{C}$ NMR $\left(100 \mathrm{MHz}, \mathrm{CD}_{2} \mathrm{Cl}_{2}, 25^{\circ} \mathrm{C}\right): \delta 14.3$, 15.0, 20.5, 23.7, 28.1, 31.8, 34.9, 36.8, 43.5, 74.1, 74.7, 80.7, 82.1, 83.0, 83.3, 84.5, 98.0, 103.3, 109.7, 110.1, $117.8\left(p-B\left(A r^{F}\right)_{4}\right), 125.4\left(C F_{3}-B\left(A r^{F}\right)_{4}\right), 129.2\left(m-B\left(A r^{F}\right)_{4}\right), 135.1$ $\left(o-B\left(A r^{F}\right)_{4}\right), 162.1\left(i p s o-B\left(A r^{F}\right)_{4}\right)$. MS (ESI) $m / z$ calcd. for $\left[\mathrm{C}_{80} \mathrm{H}_{112} \mathrm{Pd}_{10}\right]^{2+}$ 1,068.9601, found: 1,068.9647. Anal. calcd. For $\mathrm{C}_{144} \mathrm{H}_{136} \mathrm{~B}_{2} \mathrm{~F}_{48} \mathrm{Pd}_{10}$ : C, 44.76; $\mathrm{H}, 3.55$, found: $\mathrm{C}, 44.77 ; \mathrm{H}, 3.73$. A single crystal suitable for X-ray crystallographic analysis was grown from a $\mathrm{CH}_{2} \mathrm{Cl}_{2}$-Toluene solution (Supplementary Methods). For 1-rac: ${ }^{1} \mathrm{H}$ NMR $\left(400 \mathrm{MHz}, \mathrm{CD}_{2} \mathrm{Cl}_{2}, 25^{\circ} \mathrm{C}\right): \delta-0.72(\mathrm{~s}, 12 \mathrm{H}), 0.20(\mathrm{~s}, 12 \mathrm{H}), 0.38(\mathrm{~s}, 12 \mathrm{H})$, $1.40(\mathrm{~m}, 4 \mathrm{H}), 1.70(\mathrm{~m}, 4 \mathrm{H}), 1.73(\mathrm{~s}, 12 \mathrm{H}), 1.80(\mathrm{~m}, 4 \mathrm{H}), 1.83(\mathrm{~s}, 12 \mathrm{H}), 2.08(\mathrm{~m}, 4 \mathrm{H})$, $2.77(\mathrm{~d}, J=12 \mathrm{~Hz}, 4 \mathrm{H}), 2.80(\mathrm{~d}, J=12 \mathrm{~Hz}, 4 \mathrm{H}), 2.85(\mathrm{~d}, J=12 \mathrm{~Hz}, 4 \mathrm{H}), 3.03(\mathrm{~d}$, $J=12 \mathrm{~Hz}, 4 \mathrm{H}), 3.07(\mathrm{dd}, J=3 \mathrm{~Hz}, J=9 \mathrm{~Hz}, 4 \mathrm{H}), 3.33(\mathrm{~m}, 4 \mathrm{H}), 3.34(\mathrm{t}, J=12 \mathrm{~Hz}$, $4 \mathrm{H}), 3.46(\mathrm{dd}, J=3 \mathrm{~Hz}, J=9 \mathrm{~Hz}, 4 \mathrm{H}), 3.52(\mathrm{~m}, 4 \mathrm{H}), 7.30\left(\mathrm{~s}, 8 \mathrm{H}, p-B\left(A r^{F}\right)_{4}\right), 7.65(\mathrm{~s}$, $\left.16 \mathrm{H}, o-B\left(A r^{F}\right)_{4}\right) \cdot{ }^{13} \mathrm{C}$ NMR $\left(100 \mathrm{MHz}, \mathrm{CD}_{2} \mathrm{Cl}_{2}, 25^{\circ} \mathrm{C}\right): \delta 13.7,13.8,20.0,24.4,29.4$ 29.7, 34.4, 36.5, 43.1, 69.3, 76.5, 79.5, 84.0, 87.5, 88.1, 89.3, 95.0, 96.1, 99.4, 108.1, $117.8\left(p-B\left(A r^{F}\right)_{4}\right), 125.4\left(C F_{3}-B\left(A r^{F}\right)_{4}\right), 129.2\left(m-B\left(A r^{F}\right)_{4}\right), 135.1\left(o-B\left(A r^{F}\right)_{4}\right), 162.1$ (ipso- $B\left(A r^{F}\right)_{4}$ ). MS (ESI) $\mathrm{m} / z$ calcd. for $\left[\mathrm{C}_{80} \mathrm{H}_{112} \mathrm{Pd}_{10}\right]^{2+}: 1,068.9601$, found: 1,068.9432. Anal. calcd. For $\mathrm{C}_{144} \mathrm{H}_{136} \mathrm{~B}_{2} \mathrm{~F}_{48} \mathrm{Pd}_{10} \cdot \mathrm{C}_{6} \mathrm{H}_{14}$ : C, 45.60; $\mathrm{H}, 3.83$, found: $\mathrm{C}$, 45.48; H, 3.99. A single crystal suitable for X-ray crystallographic analysis was grown from a diethylether - hexane solution (Supplementary Methods).

Synthesis of $\left[\mathbf{P d}_{5}(\boldsymbol{\beta} \text {-carotene })_{2}\right]\left[\mathbf{B}\left(\mathbf{A r}^{\mathbf{F}}\right)_{\mathbf{4}}\right]_{\mathbf{2}}$ (2-meso). CO gas $(1 \mathrm{~atm})$ was bubbled in a $\mathrm{CH}_{2} \mathrm{Cl}_{2}$ solution $(220 \mathrm{ml})$ of $\left[\mathrm{Pd}_{10}(\beta \text {-carotene })_{2}\right]\left[\mathrm{B}\left(\mathrm{Ar}^{\mathrm{F}}\right)_{4}\right]_{2}$ (1-meso) $(340 \mathrm{mg}, 88.0 \mu \mathrm{mol})$ at $5^{\circ} \mathrm{C}$ for $24 \mathrm{~h}$. The reaction mixture was filtered and the filtrate was dried in vacuo to give a dark brown powder. After extraction with $\mathrm{CH}_{3} \mathrm{CN}$, the volatiles were removed in vacuo to give $\left[\mathrm{Pd}_{5}(\beta \text {-carotene })_{2}\right]\left[\mathrm{B}\left(\mathrm{Ar}^{\mathrm{F}}\right)_{4}\right]_{2}$ (2-meso) as a dark brown powder $(218 \mathrm{mg}, 74 \%) .{ }^{1} \mathrm{H}$ NMR $\left(400 \mathrm{MHz}, \mathrm{CD}_{2} \mathrm{Cl}_{2}\right.$, $\left.25^{\circ} \mathrm{C}\right): \delta-0.29(\mathrm{~s}, 6 \mathrm{H}), 0.05(\mathrm{~s}, 6 \mathrm{H}), 0.90(\mathrm{~s}, 6 \mathrm{H}), 1.05(\mathrm{~s}, 6 \mathrm{H}), 1.06(\mathrm{~s}, 6 \mathrm{H}), 1.47(\mathrm{~m}$, $4 \mathrm{H}), 1.60(\mathrm{~s}, 6 \mathrm{H}), 1.60-1.68(\mathrm{~m}, 8 \mathrm{H}), 1.74(\mathrm{~s}, 6 \mathrm{H}), 1.92-2.08(\mathrm{~m}, 6 \mathrm{H}), 1.94(\mathrm{~s}, 6 \mathrm{H})$, $1.98(\mathrm{~s}, 6 \mathrm{H}), 2.02(\mathrm{~d}, J=12 \mathrm{~Hz}, 2 \mathrm{H}), 2.06(\mathrm{~s}, 6 \mathrm{H}), 2.12(\mathrm{~m}, 2 \mathrm{H}), 2.39(\mathrm{~d}, J=12 \mathrm{~Hz}$, $2 \mathrm{H}), 2.52(\mathrm{~d}, J=12 \mathrm{~Hz}, 2 \mathrm{H}), 2.92(\mathrm{t}, J=12 \mathrm{~Hz}, 2 \mathrm{H}), 2.96(\mathrm{t}, J=12 \mathrm{~Hz}, 2 \mathrm{H}), 3.3(\mathrm{~m}$, $4 \mathrm{H}), 3.67(\mathrm{t}, J=12 \mathrm{~Hz}, 2 \mathrm{H}), 5.13(\mathrm{t}, J=12 \mathrm{~Hz}, 2 \mathrm{H}), 5.85(\mathrm{t}, J=12 \mathrm{~Hz}, 2 \mathrm{H}), 6.10(\mathrm{~d}$, $J=12 \mathrm{~Hz}, 2 \mathrm{H}), 6.15(\mathrm{~d}, J=16 \mathrm{~Hz}, 2 \mathrm{H}), 6.22(\mathrm{~d}, J=12 \mathrm{~Hz}, 2 \mathrm{H}), 6.26(\mathrm{~d}, J=16 \mathrm{~Hz}$ $2 \mathrm{H}), 6.29(\mathrm{~d}, J=16 \mathrm{~Hz}, 2 \mathrm{H}), 6.91(\mathrm{dd}, J=12 \mathrm{~Hz}, J=16 \mathrm{~Hz}, 2 \mathrm{H}), 7.49(\mathrm{~s}, 8 \mathrm{H}, p-$ $\left.B\left(A r^{F}\right)_{4}\right), 7.64\left(\mathrm{~s}, 16 \mathrm{H}, o-B\left(A r^{F}\right)_{4}\right) \cdot{ }^{13} \mathrm{C}$ NMR $\left(100 \mathrm{MHz}, \mathrm{CD}_{2} \mathrm{Cl}_{2}, 25^{\circ} \mathrm{C}\right): \delta 13.0$ 13.3, 14.0, 14.2, 19.6, 19.9, 22.1, 24.0, 28.0, 29.2, 29.4, 31.6, 33.7, 34.6, 35.0, 36.8, 40.1, 42.7, 76.8, 78.9, 79.7, 89.2, 89.4, 89.6, 91.8, 92.5, 103.5, 111.8, 112.3, 117.8 ( $\left.B\left(A r^{F}\right)_{4}\right), 123.4,125.5\left(C F_{3}-B\left(A r^{F}\right)_{4}\right), 126.7,129.2\left(m-B\left(A r^{F}\right)_{4}\right), 129.3,129.9,130.4$, 130.6, $135.1\left(o-B\left(A r^{F}\right)_{4}\right), 135.7,137.6,138.0,140.3,143.9,162.1\left(\right.$ ipso- $\left.B\left(A r^{F}\right)_{4}\right)$. MS (ESI) $\mathrm{m} / z$ calcd. for $\left[\mathrm{C}_{80} \mathrm{H}_{112} \mathrm{Pd}_{5}\right]^{2+}: 802.6996$, found: 802.7014 . Anal. calcd. For $\mathrm{C}_{144} \mathrm{H}_{136} \mathrm{~B}_{2} \mathrm{~F}_{48} \mathrm{Pd}_{5} \cdot \mathrm{C}_{6} \mathrm{H}_{6}$ : C, 52.83; H, 4.20, found: $\mathrm{C}, 52.65 ; \mathrm{H}, 4.35$. A single crystal suitable for X-ray crystallographic analysis was grown from a diethyletherbenzene solution (Supplementary Methods).

Synthesis of $\left[\mathbf{P d}_{\mathbf{7}}(\boldsymbol{\beta} \text {-carotene })_{\mathbf{2}}\right]\left[\mathbf{B}\left(\mathbf{A r}^{\mathbf{F}}\right)_{\mathbf{4}}\right]_{\mathbf{2}}$ (3-meso). CO gas ( $\left.1 \mathrm{~atm}\right)$ was bubbled in a $\mathrm{CH}_{2} \mathrm{Cl}_{2}$ solution $(100 \mathrm{ml})$ of $\left[\mathrm{Pd}_{10}(\beta \text {-carotene })_{2}\right]\left[\mathrm{B}\left(\mathrm{Ar}^{\mathrm{F}}\right)_{4}\right]_{2}$ (1-meso) $(107 \mathrm{mg}, 27.8 \mu \mathrm{mol})$ at $30^{\circ} \mathrm{C}$ for $3 \mathrm{~h}$ in the dark. The reaction mixture was filtered and the filtrate was dried in vacuo to give a dark red powder. The resultant powder was washed with $\mathrm{CH}_{3} \mathrm{CN}$ and dried in vacuo. $\mathrm{Et}_{2} \mathrm{O}$ was added and the mixture was filtered. The filtrate was dried in vacuo to give $\left[\mathrm{Pd}_{7}(\beta-\right.$ carotene $\left.)_{2}\right]\left[\mathrm{B}\left(\mathrm{Ar}^{\mathrm{F}}\right)_{4}\right]_{2}\left(3\right.$-meso) as a red powder $(20.0 \mathrm{mg}, 20 \%) .{ }^{1} \mathrm{H}$ NMR $(400 \mathrm{MHz}$ $\left.\mathrm{CD}_{2} \mathrm{Cl}_{2}, 25^{\circ} \mathrm{C}\right): \delta-0.27(\mathrm{~s}, 6 \mathrm{H}),-0.04(\mathrm{~s}, 6 \mathrm{H}), 0.07(\mathrm{~s}, 6 \mathrm{H}), 0.67(\mathrm{~s}, 6 \mathrm{H}), 1.12$ $(\mathrm{s}, 6 \mathrm{H}), 1.13(\mathrm{~s}, 6 \mathrm{H}), 1.51(\mathrm{~m}, 4 \mathrm{H}), 1.59(\mathrm{~s}, 6 \mathrm{H}), 1.61-1.70(\mathrm{~m}, 6 \mathrm{H}), 1.79(\mathrm{~s}, 6 \mathrm{H})$ $1.97(\mathrm{~m}, 2 \mathrm{H}), 2.06(\mathrm{~s}, 6 \mathrm{H}), 2.06-2.15(\mathrm{~m}, 8 \mathrm{H}), 2.23(\mathrm{~d}, J=12 \mathrm{~Hz}, 2 \mathrm{H}), 2.33(\mathrm{~d}$, $J=12 \mathrm{~Hz}, 2 \mathrm{H}), 2.34(\mathrm{~s}, 6 \mathrm{H}), 2.40(\mathrm{t}, J=12 \mathrm{~Hz}, 2 \mathrm{H}), 2.79(\mathrm{~d}, J=12 \mathrm{~Hz}, 2 \mathrm{H}), 2.85$ $(\mathrm{d}, J=12 \mathrm{~Hz}, 2 \mathrm{H}), 3.03(\mathrm{~d}, J=12 \mathrm{~Hz}, 2 \mathrm{H}), 3.27(\mathrm{~d}, J=12 \mathrm{~Hz}, 2 \mathrm{H}), 3.34(\mathrm{~m}, 4 \mathrm{H})$, $3.56(\mathrm{t}, J=12 \mathrm{~Hz}, 2 \mathrm{H}), 3.65(\mathrm{~d}, J=12 \mathrm{~Hz}, 2 \mathrm{H}), 4.50(\mathrm{~d}, J=12 \mathrm{~Hz}, 2 \mathrm{H}), 6.08$ $(\mathrm{d}, J=12 \mathrm{~Hz}, 2 \mathrm{H}), 6.28(\mathrm{~d}, J=16 \mathrm{~Hz}, 2 \mathrm{H}), 6.44(\mathrm{~d}, J=16 \mathrm{~Hz}, 2 \mathrm{H}), 6.46(\mathrm{t}, J=12$ $\mathrm{Hz}, 2 \mathrm{H}), 7.48\left(\mathrm{~s}, 8 \mathrm{H}, p-B\left(A r^{F}\right)_{4}\right), 7.63\left(\mathrm{~s}, 16 \mathrm{H}, o-B\left(A r^{F}\right)_{4}\right) .{ }^{3} \mathrm{C}$ NMR $(100 \mathrm{MHz}$, $\left.\mathrm{CD}_{2} \mathrm{Cl}_{2}, 25^{\circ} \mathrm{C}\right): \delta 13.6,14.4,14.6,14.7,19.6,20.2,22.2,23.9,28.0,29.3,29.5$, $31.7,34.0,34.5,34.9,36.7,40.2,43.0,75.5,76.8,79.0,80.3,80.6,86.7,87.9,88.8$, 89.2, 95.5, 96.1, 96.4, 100.9, 103.5, 111.2, 117.1, $117.8\left(p-B\left(A r^{F}\right)_{4}\right), 125.5\left(C_{3^{-}}\right.$ $\left.B\left(A r^{F}\right)_{4}\right), 127.2,129.2\left(m-B\left(A r^{F}\right)_{4}\right), 129.4,131.5,135.1\left(o-B\left(A r^{F}\right)_{4}\right), 136.6,137.6$, $140.4,162.1\left(\right.$ ipso- $\left.B\left(\mathrm{Ar}^{\mathrm{F}}\right)_{4}\right)$. MS (ESI) $\mathrm{m} / z$ calcd. for $\left[\mathrm{C}_{80} \mathrm{H}_{112} \mathrm{Pd}_{7}\right]^{2+}: 909.1038$, found: 909.1082. Anal. calcd. For $\mathrm{C}_{144} \mathrm{H}_{136} \mathrm{~B}_{2} \mathrm{~F}_{48} \mathrm{Pd}_{7} \cdot\left(\mathrm{C}_{6} \mathrm{H}_{6}\right)_{2}$ : C, 50.62; $\mathrm{H}$, 4.03, found: $\mathrm{C}, 50.73 ; \mathrm{H}, 4.06$. A single crystal suitable for X-ray crystallographic 
analysis was grown from a diethylether-benzene solution (Supplementary Methods).

\section{Synthesis of $\left[\mathbf{P d}_{\mathbf{5}} \mathbf{P t}_{\mathbf{3}}(\boldsymbol{\beta} \text {-carotene })_{\mathbf{2}}\right]\left[\mathbf{B}\left(\mathbf{A r} \mathbf{F}_{\mathbf{4}}\right]_{\mathbf{2}}\right.$ (4-meso). Ethylene gas (1 atm)} was bubbled in a $\mathrm{CH}_{2} \mathrm{Cl}_{2}$ solution $(30 \mathrm{ml})$ of $\left[\mathrm{Pd}_{5}(\beta \text {-carotene })_{2}\right]\left[\mathrm{B}\left(\mathrm{Ar}^{\mathrm{F}}\right)_{4}\right]_{2}$ (2meso) $(54.0 \mathrm{mg}, 16.2 \mu \mathrm{mol})$ and $\mathrm{Pt}_{2}(\mathrm{dba})_{3} \cdot\left(\mathrm{CHCl}_{3}\right)(100 \mathrm{mg}, 82.5 \mu \mathrm{mol})$ at r.t. for $5 \mathrm{~min}$. After the solution was stirred at $30^{\circ} \mathrm{C}$ for 1 day, the colour turned dark brown. The reaction mixture was dried in vacuo to give a dark brown powder. After extraction with $\mathrm{Et}_{2} \mathrm{O}$ and washing with $\mathrm{C}_{6} \mathrm{H}_{6},\left[\mathrm{Pd}_{5} \mathrm{Pt}_{3}(\beta\right.$-carotene $\left.)_{2}\right]\left[\mathrm{B}\left(\mathrm{Ar}^{\mathrm{F}}\right)_{4}\right]_{2}$ (4-meso) was isolated as a yellow solid $(37.6 \mathrm{mg}, 59 \%) .{ }^{1} \mathrm{H}$ NMR $\left(400 \mathrm{MHz}, \mathrm{CD}_{2} \mathrm{Cl}_{2}, 25^{\circ} \mathrm{C}\right): \delta-0.28(\mathrm{~s}, 6 \mathrm{H}),-0.11(\mathrm{~s}, 6 \mathrm{H}), 0.50(\mathrm{~s}, 12 \mathrm{H}), 1.17(\mathrm{~s}, 6 \mathrm{H})$, $1.21(\mathrm{~s}, 6 \mathrm{H}), 1.56(\mathrm{~s}, 6 \mathrm{H}), 1.56-1.59(\mathrm{~m}, 4 \mathrm{H}), 1.60-1.72(\mathrm{~m}, 8 \mathrm{H}), 1.84(\mathrm{~s}, 6 \mathrm{H}), 1.98$ $(\mathrm{m}, 2 \mathrm{H}), 2.01(\mathrm{~s}, 6 \mathrm{H}), 2.07(\mathrm{~s}, 6 \mathrm{H}), 2.09(\mathrm{~m}, 2 \mathrm{H}), 2.13-2.18(\mathrm{~m}, 4 \mathrm{H}), 2.34(\mathrm{~d}$, $J=12 \mathrm{~Hz}, 2 \mathrm{H}), 2.36(\mathrm{~d}, J=12 \mathrm{~Hz}, 2 \mathrm{H}), 2.43(\mathrm{t}, J=12 \mathrm{~Hz}, 2 \mathrm{H}), 2.71(\mathrm{~d}, J=12 \mathrm{~Hz}$, $2 \mathrm{H}), 2.76(\mathrm{~d}, J=14 \mathrm{~Hz}, 2 \mathrm{H}), 2.81(\mathrm{~d}, J=12 \mathrm{~Hz}, 2 \mathrm{H}), 3.00(\mathrm{t}, J=11 \mathrm{~Hz}, 2 \mathrm{H}), 3.04(\mathrm{~d}$ $J=12 \mathrm{~Hz}, 2 \mathrm{H}), 3.11(\mathrm{~d}, J=12 \mathrm{~Hz}, 2 \mathrm{H}), 3.3(\mathrm{~m}, 4 \mathrm{H}), 3.40(\mathrm{~m}, 2 \mathrm{H}), 3.48$ (t, $J=12 \mathrm{~Hz}$, $2 \mathrm{H}), 3.79(\mathrm{~d}, J=11 \mathrm{~Hz}, 2 \mathrm{H}), 6.47(\mathrm{~d}, J=16 \mathrm{~Hz}, 2 \mathrm{H}), 6.68(\mathrm{~d}, J=16 \mathrm{~Hz}, 2 \mathrm{H}), 7.49(\mathrm{~s}$, $\left.8 \mathrm{H}, p-B\left(A r^{F}\right)_{4}\right), 7.65\left(\mathrm{~s}, 16 \mathrm{H}, o-B\left(A r^{F}\right)_{4}\right) .{ }^{13} \mathrm{C} \mathrm{NMR}\left(100 \mathrm{MHz}, \mathrm{CD}_{2} \mathrm{Cl}_{2}, 25^{\circ} \mathrm{C}\right): \delta$ $14.3,14.6,15.5,17.5,19.7,20.3,22.2,23.8,28.0,29.2,29.7,31.7,33.9,34.7,34.9$, $36.8,40.1,43.2,64.4,67.3,74.9,75.1,75.9,78.1,78.7,79.9,80.6,85.2,85.7,87.6$, 96.9, 98.4, 98.6, 103.5, 110.6, 114.4, $117.8\left(p-B\left(A r^{F}\right)_{4}\right), 125.5\left(C F_{3}-B\left(A r^{F}\right)_{4}\right), 129.1$, 129.2 $\left(m-B\left(A r^{F}\right)_{4}\right), 132.3,135.1\left(o-B\left(A r^{F}\right)_{4}\right), 136.0,136.5,162.1\left(i p s o-B\left(A r^{F}\right)_{4}\right) . \mathrm{MS}$ (ESI) $\mathrm{m} / z$ calcd. for $\left[\mathrm{C}_{80} \mathrm{H}_{112} \mathrm{Pd}_{5} \mathrm{Pt}_{3}\right]^{2+}: 1,095.1460$, found: 1095.1291 . Anal. calcd. For $\mathrm{C}_{144} \mathrm{H}_{136} \mathrm{~B}_{2} \mathrm{~F}_{48} \mathrm{Pd}_{5} \mathrm{Pt}_{3} \cdot\left(\mathrm{C}_{6} \mathrm{H}_{6}\right)_{2}$ : C, 45.99; $\mathrm{H}, 3.66$, found: $\mathrm{C}, 46.10 ; \mathrm{H}, 3.86$. A single crystal suitable for $\mathrm{X}$-ray crystallographic analysis was grown from a dichloromethane-benzene solution (Supplementary Methods).

Synthesis of $\left[\mathbf{P d}_{5} \mathbf{P t}_{3} \mathbf{P d}_{\mathbf{2}}(\boldsymbol{\beta} \text {-carotene })_{2}\right]\left[\mathbf{B}(\mathbf{A r})_{4}\right)_{2}$ (5-meso). To a solution of $\left[\mathrm{Pd}_{5} \mathrm{Pt}_{3}(\beta \text {-carotene })_{2}\right]\left[\mathrm{B}\left(\mathrm{Ar}^{\mathrm{F}}\right)_{4}\right]_{2}$ (4-meso) $(58.0 \mathrm{mg}, 14.8 \mu \mathrm{mol})$ in $\mathrm{ClCH}_{2} \mathrm{CH}_{2} \mathrm{Cl}$ $(50 \mathrm{ml})$ was added $\mathrm{Pd}_{2}(\mathrm{dba})_{3} \cdot\left(\mathrm{C}_{6} \mathrm{H}_{6}\right)(200 \mathrm{mg}, 201 \mu \mathrm{mol})$, and the reaction mixture was stirred under nitrogen atmosphere at $70^{\circ} \mathrm{C}$ for $12 \mathrm{~h}$. The mixture was filtered and the filtrate was dried in vacuo. After reprecipitation with $\mathrm{CH}_{2} \mathrm{Cl}_{2} /$ hexane, the yellow powder was obtained. After drying in vacuo, the product was analysed by $\mathrm{NMR}$, showing that $\left[\mathrm{Pd}_{5} \mathrm{Pt}_{3} \mathrm{Pd}_{2}(\beta \text {-carotene })_{2}\right]\left[\mathrm{B}\left(\mathrm{Ar}^{\mathrm{F}}\right)_{4}\right]_{2}(\mathbf{5}$-meso $)$ was formed as a major product with an unidentified minor product (major:minor $=8: 2$; a mixture of two products: $43 \mathrm{mg})$. For 5-meso: ${ }^{1} \mathrm{H}$ NMR $\left(600 \mathrm{MHz}, \mathrm{CD}_{2} \mathrm{Cl}_{2}, 25^{\circ} \mathrm{C}\right): \delta-0.27$ $(\mathrm{s}, 6 \mathrm{H}),-0.22(\mathrm{~s}, 6 \mathrm{H}),-0.17(\mathrm{~s}, 6 \mathrm{H}), 0.11(\mathrm{~s}, 6 \mathrm{H}), 0.31(\mathrm{~s}, 6 \mathrm{H}), 1.01(\mathrm{~s}, 6 \mathrm{H}), 1.48$ (s, $6 \mathrm{H}), 1.54(\mathrm{~s}, 6 \mathrm{H}), 1.63(\mathrm{~m}, 4 \mathrm{H}), 1.78(\mathrm{~m}, 4 \mathrm{H}), 1.98(\mathrm{~m}, 4 \mathrm{H}), 2.05(\mathrm{~s}, 6 \mathrm{H}), 2.08(\mathrm{~m}$, $4 \mathrm{H}), 2.09$ (s, 6H), $2.52(\mathrm{~d}, J=12 \mathrm{~Hz}, 2 \mathrm{H}), 2.56(\mathrm{~d}, J=12 \mathrm{~Hz}, 2 \mathrm{H}), 2.60$ (t, $J=12 \mathrm{~Hz}$, $2 \mathrm{H}), 2.62(\mathrm{~d}, J=12 \mathrm{~Hz}, 2 \mathrm{H}), 2.66(\mathrm{~d}, J=12 \mathrm{~Hz}, 2 \mathrm{H}), 2.74(\mathrm{~d}, J=12 \mathrm{~Hz}, 2 \mathrm{H}), 2.90$ $(\mathrm{d}, J=12 \mathrm{~Hz}, 4 \mathrm{H}), 2.91(\mathrm{~d}, J=12 \mathrm{~Hz}, 2 \mathrm{H}), 2.95(\mathrm{~d}, J=12 \mathrm{~Hz}, 2 \mathrm{H}), 3.07(\mathrm{~d}$, $J=12 \mathrm{~Hz}, 2 \mathrm{H}), 3.19(\mathrm{t}, J=12 \mathrm{~Hz}, 2 \mathrm{H}), 3.30(\mathrm{~m}, 8 \mathrm{H}), 3.40(\mathrm{t}, J=12 \mathrm{~Hz}, 2 \mathrm{H}), 3.42(\mathrm{t}$, $J=12 \mathrm{~Hz}, 2 \mathrm{H}), 7.51\left(\mathrm{~s}, 8 \mathrm{H}, p-B A r^{F}\right), 7.66\left(\mathrm{~s}, 16 \mathrm{H}, o-B A r^{F}\right) .{ }^{13} \mathrm{C}$ NMR $(150 \mathrm{MHz}$ $\left.\mathrm{CD}_{2} \mathrm{Cl}_{2}, 25^{\circ} \mathrm{C}\right): \delta 14.1,14.3,14.8,15.8,20.4,20.5,23.7,28.1,28.2,31.8,31.9,34.9$, $36.8,36.9,43.4,43.5,70.0,71.1,71.2,71.3,71.8,73.6,74.1,74.6,74.8,80.5,81.8$, $83.1,83.4,84.6,89.9,98.2,103.5,105.3,109.8,110.4,111.4,117.9\left(p-B A r^{F}\right), 125.0$ $\left(C F_{3}-B A r_{4}{ }_{4}\right), 129.2\left(m-B A r_{4}{ }_{4}\right), 135.2\left(o-B A r_{4}{ }_{4}\right), 162.1\left(i p s o-B A r^{F}\right)$. MS (ESI) $\mathrm{m} / z$ calcd. for $\left[\mathrm{C}_{80} \mathrm{H}_{112} \mathrm{Pd}_{7} \mathrm{Pt}_{3}\right]^{2+}: 1,201.5503$, found: 1,201.5553. Anal. calcd. For $\mathrm{C}_{144} \mathrm{H}_{136} \mathrm{~B}_{2} \mathrm{~F}_{48} \mathrm{Pd}_{7} \mathrm{Pt}_{3} \cdot\left(\mathrm{C}_{6} \mathrm{H}_{6}\right): \mathrm{C}, 42.81 ; \mathrm{H}, 3.40$, found: $\mathrm{C}, 42.87 ; \mathrm{H}, 3.46$. The sample suitable for elemental analysis was obtained from a dichloromethanebenzene solution. The minor product might be an isomer of 5-meso having a different metal arrangement (Supplementary Methods).

Synthesis of $\left[\mathbf{P d}_{\mathbf{2}}(\mathbf{1}, 10 \text {-diphenylpentaene })_{2}\right]\left[\mathbf{B}\left(\mathbf{A r}^{\mathbf{F}}\right)_{\mathbf{4}}\right]_{\mathbf{2}}$. To a suspension of 1,10-diphenyl-1,3,5,7,9-decapentaene $(80.0 \mathrm{mg}, 0.28 \mathrm{mmol})$ in $\mathrm{CH}_{2} \mathrm{Cl}_{2}(30 \mathrm{ml})$ was added $\left[\mathrm{Pd}_{2}(1,4\right.$-diphenyl-1,3-butadiene $\left.)\right]\left[\mathrm{B}\left(\mathrm{Ar}^{\mathrm{F}}\right)_{4}\right]_{2}(299.6 \mathrm{mg}, 0.13 \mathrm{mmol})$. The mixture was stirred for $1 \mathrm{~h}$ at r.t. The reaction mixture was filtered and poured into hexane to give deep-green precipitation. $\left[\mathrm{Pd}_{2}(1,10 \text {-diphenylpentaene })_{2}\right][-$ $\left.\mathrm{B}\left(\mathrm{Ar}^{\mathrm{F}}\right)_{4}\right]_{2}$ was isolated as a mixture of four isomers by recrystallization $(262.1 \mathrm{mg}$, $82 \%$, isomer ratio 57:27:10:6). ${ }^{1} \mathrm{H} \mathrm{NMR}\left(600 \mathrm{MHz}, \mathrm{CD}_{2} \mathrm{Cl}_{2}, 25^{\circ} \mathrm{C}\right)$ of vinyl protons in A (57\% of products): $\delta 3.30(\mathrm{dd}, J=12 \mathrm{~Hz}, J=12 \mathrm{~Hz}, 1 \mathrm{H}), 3.38(\mathrm{dd}, J=12 \mathrm{~Hz}$ $J=12 \mathrm{~Hz}, 1 \mathrm{H}), 3.54(\mathrm{dd}, J=12 \mathrm{~Hz}, J=12 \mathrm{~Hz}, 1 \mathrm{H}), 3.75(\mathrm{dd}, J=11 \mathrm{~Hz}, J=12 \mathrm{~Hz}$, $1 \mathrm{H}), 4.29(\mathrm{dd}, J=11 \mathrm{~Hz}, J=13 \mathrm{~Hz}, 1 \mathrm{H}), 4.33(\mathrm{dd}, J=11 \mathrm{~Hz}, J=12 \mathrm{~Hz}, 1 \mathrm{H}), 4.48$ $(\mathrm{dd}, J=12 \mathrm{~Hz}, J=13 \mathrm{~Hz}, 1 \mathrm{H}), 5.07(\mathrm{dd}, J=12 \mathrm{~Hz}, J=14 \mathrm{~Hz}, 1 \mathrm{H}), 5.52$ (dd, $J=12 \mathrm{~Hz}, J=13 \mathrm{~Hz}, 1 \mathrm{H}), 5.77(\mathrm{dd}, J=11 \mathrm{~Hz}, J=13 \mathrm{~Hz}, 1 \mathrm{H}), 5.90(\mathrm{dd}, J=11 \mathrm{~Hz}$, $J=15 \mathrm{~Hz}, 1 \mathrm{H}), 6.05(\mathrm{dd}, J=12 \mathrm{~Hz}, J=14 \mathrm{~Hz}, 1 \mathrm{H}), 6.08(\mathrm{dd}, J=11 \mathrm{~Hz}, J=15 \mathrm{~Hz}$, $1 \mathrm{H}), 6.14(\mathrm{~d}, J=14 \mathrm{~Hz}, 1 \mathrm{H}), 6.21(\mathrm{dd}, J=11 \mathrm{~Hz}, J=15 \mathrm{~Hz}, 1 \mathrm{H}), 6.40(\mathrm{dd}, J=11$ $\mathrm{Hz}, J=11 \mathrm{~Hz}, 1 \mathrm{H}), 6.47(\mathrm{dd}, J=11 \mathrm{~Hz}, J=14 \mathrm{~Hz}, 1 \mathrm{H}), 6.50(\mathrm{~d}, J=15 \mathrm{~Hz}, 1 \mathrm{H})$, $6.69(\mathrm{~d}, J=15 \mathrm{~Hz}, 1 \mathrm{H}), 6.71(\mathrm{dd}, J=15 \mathrm{~Hz}, 1 \mathrm{H}) . \mathbf{B}$ or $\mathbf{C}(27 \%$ of products $): \delta 3.34$ $(\mathrm{dd}, J=11 \mathrm{~Hz}, J=11 \mathrm{~Hz}, 2 \mathrm{H}), 3.69(\mathrm{dd}, J=11 \mathrm{~Hz}, J=11 \mathrm{~Hz}, 2 \mathrm{H}), 4.32$ (dd, $J=11 \mathrm{~Hz}, J=13 \mathrm{~Hz}, 2 \mathrm{H}), 4.98(\mathrm{dd}, J=11 \mathrm{~Hz}, J=14 \mathrm{~Hz}, 2 \mathrm{H}), 5.46(\mathrm{dd}, J=12 \mathrm{~Hz}$, $J=14 \mathrm{~Hz}, 2 \mathrm{H}), 5.76(\mathrm{dd}, J=12 \mathrm{~Hz}, 13 \mathrm{~Hz}, 2 \mathrm{H}), 6.21(\mathrm{dd}, J=11 \mathrm{~Hz}, J=14 \mathrm{~Hz}, 2 \mathrm{H})$, $6.42(\mathrm{~d}, J=14 \mathrm{~Hz}, 2 \mathrm{H}), 6.61(\mathrm{dd}, J=11 \mathrm{~Hz}, J=15 \mathrm{~Hz}, 2 \mathrm{H}), 6.80(\mathrm{dd}, J=15 \mathrm{~Hz}$, $2 \mathrm{H})$. B or $\mathbf{C}(10 \%$ of products): $\delta 3.30(\mathrm{dd}, J=11 \mathrm{~Hz}, J=11 \mathrm{~Hz}, 2 \mathrm{H}), 3.78(\mathrm{dd}$, $J=11 \mathrm{~Hz}, J=11 \mathrm{~Hz}, 2 \mathrm{H}), 4.23(\mathrm{dd}, J=11 \mathrm{~Hz}, J=13 \mathrm{~Hz}, 2 \mathrm{H}), 5.03(\mathrm{dd}, J=11 \mathrm{~Hz}$, $J=14 \mathrm{~Hz}, 2 \mathrm{H})$, ca. $5.46(2 \mathrm{H}), 6.13(\mathrm{~d}, J=14 \mathrm{~Hz}, 2 \mathrm{H}), 6.31(\mathrm{dd}, J=11 \mathrm{~Hz}, J=15 \mathrm{~Hz}$, $2 \mathrm{H})$, ca. $6.51(2 \mathrm{H}), 6.56(\mathrm{dd}, J=11 \mathrm{~Hz}, J=14 \mathrm{~Hz}, 2 \mathrm{H}), 7.01(\mathrm{dd}, J=15 \mathrm{~Hz}, 2 \mathrm{H}) . \mathbf{D}$ (6\% of products): $\delta 3.48(\mathrm{~m}, 4 \mathrm{H}), 4.49(\mathrm{~m}, 4 \mathrm{H}), 6.01(\mathrm{dd}, J=11 \mathrm{~Hz}, J=13 \mathrm{~Hz}, 4 \mathrm{H})$, $6.18(\mathrm{dd}, J=11 \mathrm{~Hz}, J=15 \mathrm{~Hz}, 4 \mathrm{H}), 6.69(\mathrm{~d}, J=15.6 \mathrm{~Hz}, 4 \mathrm{H})$. Anal. calcd. For
$\mathrm{C}_{108} \mathrm{H}_{64} \mathrm{~B}_{2} \mathrm{~F}_{48} \mathrm{Pd}_{2}$ : C, 51.72; H, 2.57, found: C, 51.59; H, 2.58 (Supplementary Methods).

\section{References}

1. Polivka, T. \& Sundstrom, V. Ultrafast dynamics of carotenoid excited states - from solution to natural and artificial systems. Chem. Rev. 104, 2021-2072 (2004).

2. Polivka, T. \& Frank, H. A. Molecular factors controlling photosynthetic light harvesting by carotenoids. Acc. Chem. Res. 43, 1125-1134 (2010).

3. Takaichi, S., Mimuro, M. \& Tomita, Y. Carotenoids -Biological Functions and Diversity (Shokabo, 2006).

4. Visoly-Fisher, I. et al. Conductance of a biomolecular wire. Proc. Natl. Acad. Sci. USA 103, 8686-8690 (2006).

5. Ichikawa, M., Tsutsui, M. \& Vohwinkel, F. Iron carbonyl complexes of $\beta$-carotene and lycopene. Z. Naturforsch. B 22, 376-379 (1967).

6. Nakamura, A. \& Tsutsui, M. $\pi$-Complexes with biologically significant materials. III. Vitamin A acetate iron tricarbonyl. J. Med. Chem. 7, 335-337 (1964).

7. Birch, A. J., Fitton, H., Mason, R., Robertson, G. B. \& Stangroom, J. E. Vitamin-A aldehyde iron tricarbonyl. Chem. Commun. 613-614 (1966).

8. Mason, R. \& Robertson, G. B. Crystal and molecular structure of (vitamin-A aldehyde)tricarbonyliron. J. Chem. Soc. A 1229-1234 (1970).

9. Mashima, K. \& Nakamura, A. Adaptable coordination modes of conjugated 1,3diene: uniqueness of s-trans coordination. J. Organomet. Chem. 663, 5-12 (2002)

10. Bera, J. K. \& Dunbar, K. R. Chain compounds based on transition metal backbones: new life for an old topic. Angew. Chem. Int. Ed. 41, 4453-4457 (2002)

11. Berry, J. F. Metal-metal bonds in chains of three or more metal atoms: from homometallic to heterometallic chains. Struct. Bond 136, 1-28 (2010).

12. Zhao, Q., Harris, T. D. \& Betley, T. A. $\left[\left({ }^{\mathrm{H}} \mathrm{L}\right)_{2} \mathrm{Fe}_{6}(\mathrm{NCMe})_{\mathrm{m}}\right]^{\mathrm{n}}+(\mathrm{m}=0,2,4,6$; $\mathrm{n}=-1,0,1,2,3,4,6)$ : An electron-transfer series featuring octahedral $\mathrm{Fe}_{6}$ clusters supported by a hexaamide ligand platform. J. Am. Chem. Soc. 133, 8293-8306 (2011).

13. Kanady, J. S., Tsui, E. Y., Day, M. W. \& Agapie, T. A synthetic model of the $\mathrm{Mn}_{3} \mathrm{Ca}$ subsite of the oxygen-evolving complex in photosystem II. Science 333 733-736 (2011)

14. Sunada, Y., Haige, R., Otsuka, K., Kyushin, S. \& Nagashima, H. A ladder polysilane as a template for folding palladium nanosheets. Nat. Commun. 4, 2014 (2013).

15. Ismayilov, R. H. et al. Two Linear undecanickel mixed-valence complexes: Increasing the size and the scope of the electronic properties of nickel metal strings. Angew. Chem. Int. Ed. 50, 2045-2048 (2011).

16. Tanaka, K. et al. Programmable self-assembly of metal ions inside artificial DNA duplexes. Nat. Nanotechnol. 1, 190-194 (2006).

17. Murahashi, T., Mochizuki, E., Kai, Y. \& Kurosawa, H. Organometallic sandwich chains made of conjugated polyenes and metal-metal chains. J. Am. Chem. Soc 121, 10660-10661 (1999).

18. Tatsumi, Y., Shirato, K., Murahashi, T., Ogoshi, S. \& Kurosawa, H. Sandwich complexes containing bent palladium chains. Angew. Chem. Int. Ed. 45, 5799-5803 (2006).

19. Murahashi, T. et al. Discrete sandwich compounds of monolayer palladium sheets. Science 313, 1104-1107 (2006).

20. Murahashi, T., Inoue, R., Usui, K. \& Ogoshi, S. Square tetrapalladium sheet sandwich complexes: Cyclononatetraenyl as a versatile face-capping ligand. J. Am. Chem. Soc. 131, 9888-9889 (2009).

21. Mednikov, E. G. \& Dahl, L. F. Palladium: It forms unique nano-sized carbonyl clusters. J. Chem. Edu. 86, 1135 (2009).

22. Murahashi, T. \& Kurosawa, H. Organopalladium complexes containing palladium-palladium bonds. Coord. Chem. Rev. 231, 207-228 (2002).

23. Murahashi, T., Nagai, T., Okuno, T., Matsutani, T. \& Kurosawa, H. Synthesi and ligand substitution reactions of a homoleptic acetonitrile dipalladium(I) complex. Chem. Commun. 1689-1690 (2000).

24. Ukai, T., Kawazura, H., Ishii, Y., Bonnet, J. J. \& Ibers, J. A. Chemistry of dibenzylideneacetone-palladium $(0)$ complexes: I. Nobel tris(dibenzylideneacetone)dipalladium(solvent) complexes and their reactions with quinones. J. Organomet. Chem. 65, 253-266 (1974).

25. Campbell, M. G. et al. Synthesis and structure of solution-stable onedimensional palladium wires. Nat. Chem. 3, 949-953 (2011).

26. Nakamae, K. et al. Self-alignment of low-valent octanuclear palladium atoms. Angew. Chem. Int. Ed. 54, 1016-1021 (2015).

27. Sarkar, S. et al. Metals on graphene and carbon nanotube surfaces: From mobile atoms to atomtronics to bulk metals to clusters and catalysts. Chem. Mater. 26, 184-195 (2014)

28. Chambers, A., Nemes, T., Rodriguez, N. M. \& Baker, R. T. K. Catalytic behavior of graphite nanofiber supported nickel particles. 1. Comparison with other support media. J. Phys. Chem. B 102, 2251-2258 (1998).

29. Tatsumi, Y., Nagai, T., Nakashima, H., Murahashi, T. \& Kurosawa, H. Stepwise growth of polypalladium chains in 1,4-diphenyl-1,3-butadiene sandwich complexes. Chem. Commun. 1430-1431 (2004). 
30. Diefenbach, A., Bickelhaupt, F. M. \& Frenking, G. The nature of the transition metal-carbonyl bond and the question about the valence orbitals of transition metals. A bond-energy decomposition analysis of $\mathrm{TM}(\mathrm{CO})_{6}^{\mathrm{G}}\left(\mathrm{TM}^{\mathrm{q}}=\mathrm{Hf}^{2-}\right.$, $\mathrm{Ta}^{-}, \mathrm{W}, \mathrm{Re}^{+}, \mathrm{Os}^{2+}, \mathrm{Ir}^{3+}$ ). J. Am. Chem. Soc. 122, 6449-6458 (2000).

31. Murahashi, T., Usui, K., Tachibana, Y., Kimura, S. \& Ogoshi, S. Selective construction of $\mathrm{Pd}_{2} \mathrm{Pt}$ and $\mathrm{PdPt}_{2}$ triangles in a sandwich framework: carbocyclic ligands as scaffolds for a mixed-metal system. Chem. Eur. J. 18, 8886-8890 (2012).

32. Takemoto, S. \& Matsuzaka, H. Recent advances in the chemistry of ruthenium carbido complexes. Coord. Chem. Rev. 256, 574-588 (2012).

33. Uddin, J., Dapprich, S., Frenking, G. \& Yates, B. F. Nature of the metal-alkene bond in platinum complexes of strained olefins. Organometallics 18, 457-465 (1999).

34. Stromberg, S., Svensson, M. \& Zetterberg, K. Binding of ethylene to anionic, neutral, and cationic nickel(II), palladium(II), and platinum(II) cis/trans chloride ammonia complexes. A theoretical study. Organometallics 16, 3165-3168 (1997)

35. Murahashi, T. et al. Redox-induced reversible metal assembly through translocation and reversible ligand coupling in tetranuclear metal sandwich frameworks. Nat. Chem. 4, 52-58 (2012).

36. Yanai, T., Tew, D. P. \& Handy, N. C. A new hybrid exchange-correlation functional using the Coulomb-attenuating method (CAM-B3LYP). Chem. Phys. Lett. 393, 51-57 (2004).

\section{Acknowledgements}

This work was supported by JST through PRESTO programme, JSPS and MEXT through Grants-in-aid for Scientific Research and Institute for Molecular Science. We thank

Professor H. Kurosawa and Professor S. Ogoshi for discussion.

\section{Author contributions}

The idea and plans of this research were made by T.Mu. Experiments and data analysis were performed by S.H., Y.T., M.Y., K.Y., K.M., K.T., T.Ma., S.K. and T.Mu. The theoretical calculations were performed by Y.K. and T.Y. The manuscript was co-written by T.Mu., Y.K. and T.Y. All authors discussed the results.

\section{Additional information}

Accession codes: The X-ray crystallographic coordinates for structures reported in this Article have been deposited at the Cambridge Crystallographic Data Centre (CCDC) under deposition numbers CCDC 1001723-1001727. These data can be obtained free of charge from The CCDC via www.ccdc.cam.ac.uk/data_request/cif.

Supplementary Information accompanies this paper at http://www.nature.com/ naturecommunications

Competing financial interests: The authors declare no competing financial interest.

Reprints and permission information is available online at http://npg.nature.com/ reprintsandpermissions/

How to cite this article: Horiuchi, S. et al. Multinuclear metal-binding ability of a carotene. Nat. Commun. 6:6742 doi: 10.1038/ncomms7742 (2015).

\section{(c) (1)}

This work is licensed under a Creative Commons Attribution 4.0 International License. The images or other third party material in this article are included in the article's Creative Commons license, unless indicated otherwise in the credit line; if the material is not included under the Creative Commons license, users will need to obtain permission from the license holder to reproduce the material. To view a copy of this license, visit http://creativecommons.org/licenses/by/4.0/ 